\title{
КОМПЛЕКСНА КОРЕКЦІЯ СИСТЕМИ ГІПОФІЗ-ЯЄЧНИКИ У РОБІТНИЦЬ ЛАКОФАРБОВОГО ВИРОБНИЦТВА
}

\author{
Н. М. Саннікова \\ Одеське обласне базове медичне училище
}

\begin{abstract}
У статті проаналізовано вплив шкідливих чинників на репродуктивну систему жінки-робітниці хімічного підприємства, а також обгрунтовано метод корекції порушень гормонального балансу системи гіпофіз-яєчники за допомогою ентеросорбенту «Карболонг».
\end{abstract}

\section{COMPLEX CORRECTION OF PITUITARY-OVARY SYSTEM IN EMPLOYEES OF THE DYE INDUSTRY}

\author{
N. M. Sannikova \\ Odesa State Medical College
}

The authors analyzed the scientific data about changing of the ovarium function in working women, while adapting to harm effect of the chemical factory. The sex hormone plasma levels were evaluated during the different interval time of the ovarian cycle. One could conclude there is clear dependency of the sex hormone content changing with the working time at the chemical factory. It was shown that using of enterosorbent Karbolong normalizes the sex hormone plasma levels in working women.

Вступ. У процесі адаптаці організму до несприятливого впливу виробничого довкілля (контакт зі шкідливими хімічними речовинами, вимушена робоча поза, емоційна напруженість) в жіночому організмі формуються однотипні патологічні процеси. Останні нерідко призводять до інвалідизаці жінок, запобігання якій $є$ не тільки медичною, але й соціальною проблемою $[4,7,8]$.

Основна частина. Наукові публікаці щодо ролі статевих гормонів у формуванні адаптаційних реакцій у жінок дітородного віку, які працюють в умовах шкідливого впливу факторів хімічних виробництв (зокрема, бензолу, ксилолу, толуолу), нечисленні й суперечливі.

Мета роботи полягала у вивченні особливостей функці яєчників у реалізаці адаптаційного ефекту в жінок-робітниць лакофарбового виробництва і розробці методу ефективно негормонально корекці, заснованого на нормалізаці процесів гомеостазу шляхом детоксикаці організму із застосуванням природного ентеросорбенту пролонговано ді - «Карболонг».

\footnotetext{
(ㄱ) Н. М. Саннікова, 2015
}

У роботі використовували клінічні, радіоімунологічні методи дослідження статевих гормонів (естрадіолу і прогестерону) з наборами реактивів фірми Hoffmann-La-Roche. Рівень гормонів досліджували тричі протягом менструального циклу: на 7-9, 13-15 та 21-25-й дні. Забір крові здійснювали завжди в певний час доби.

Для визначення характеру циклу (овуляторний, ановуляторний) використовували тести функціонально діагностики (кольпоцитограму, базальну температуру, феномен «зіниці» і «папороті»).

Проведено клініко-лабораторне обстеження 160 робітниць лакофарбового виробництва від 18 до 40 років. Було виділено три клінічні підгрупи залежно від стажу роботи (1-3 р., 3-6 р., понад 6 років), що налічували 123 жінки. Вивчені і проаналізовані зміни рівнів гонадотропних та стеро дних гормонів, деякі показники протеазо-інгібіторно системи, а також біохімічні показники функціонального стану печінки. Констатовано гіперпролактинемію і гіперестрогенемію на тлі низького рівня ФСГ, ЛГ і прогестерону в 1-й підгрупі, гіпопрогестеронемію - у 2-й підгрупі в жінок з ановуляцією. У 3-й підгрупі всі показники мали низький рівень, за виключенням рівня 
ЛГ. Істотні зміни показників мали місце у протеолітичній системі і Функціональному стані печінки [1]. 3 метою корекці гомеостазу і детоксикаці організму робітниць був застосований лікувально-профілактичний комплекс із ентеросорбентом «Карболонг», ефективність якого чітко виявилася у 1-й та 2-й стажових підгрупах по всіх досліджених клініко-лабораторних показниках. У 3-й підгрупі (стаж роботи понад 6 років) нормалізаці показників гормонально та протеазо-інгібіторно систем після лікування не відбулося, що свідчить про профілактичний характер запропонованого методу лікування [2, $3,5,6]$.

Висновки. Порівнюючи характеристики менструально функці у жінок в групах, що відрізнялися тривалістю впливу шкідливих факторів

\section{ЛITЕРАТУРА}

1. Саннікова Н. М. Комплексна корекція системи гіпофіз-яєчники у робітниць лакофрарбового виробництва : автореф. дис. на здобуття наук. ступеня канд. мед. наук / Н. М. Саннікова. - Одес. держ. мед. університет, Одеса, 2003.

2. Айламазян Э. К. Гипоталамо-гипофизарно-овариальные взаимоотношения у работниц полимерперерабатывающих предприятий / Э. К. Айламазян, И. Г. Баласанян / / Эндокринные системы организма и вредные факторы окружающей среды : материалы 4-ой Всесоюз. конф. - Л., 1991. - С. 7.

3. Крохмаль Г. Ю. Профрилактика нарушений функций репродуктивной системы женщин, индуцируемых эколого-профессиональными факторами : автореф. дис. на здобуття наук. ступеня канд. мед. наук / Г. Ю. Крохмаль. - Ростов на Дону, 1994.

4. Меерсон Ф. З. Физиология адаптивных процессов / Ф. 3. Меерсон. - М. : Медицина, 1986. - 521 с. лакофарбового виробництва, можна констатувати зниження резервних можливостей організму зі збільшенням виробничого стажу. Наслідком тривалого несприятливого контакту 3 органічними токсикантами було порушення менструально функці за типом стійко ановуляці 3 гіпоестрогенемією у робітниць зі стажем роботи більше 6-ти років, що підтверджує факт виснаження адаптаційного механізму нейроендокринно регуляці репродуктивно системи.

Застосування лікувального комплексу з ентеросорбентом «Карболонг» дало можливість відрегулювати менструальну функцію у жінок зі стажем роботи до 6-ти років і не викликало регуляторного впливу в жінок зі стажем роботи більше 6-ти років зі стійким виснаженням адаптаційних можливостей.

5. Нетрадиционные методы лечения в акушерстве и гинекологии / под ред. А. Г. Коломийцевой. - К. : Здоров'я, 1996. - 264 с.

6. Семенюк Л. Л. Вплив виробничої екосистеми на стан репродуктивного здоров'я жінок / Л. Л. Семенюк / / Тези доп. Х з'їзду акушерів-гінекологів. - Одеса, 1996. - С. 143.

7. Сивочалова О. В. Зависимость эмбриотропного эффректа от проницаемости плацентарной мембраны при воздействиях химических веществ / О. В. Сивочалова, И. В. Силантьева / / Генетика аномалий развития человека : материалы 1-го Всесоюз. совещания по тератологии. - К. : Наук. думка, 1983. - С. 94-96.

8. Фесенко М. А. К механизму нарушений репродуктивной функции при воздействии 4-бром-0-ксилола (экспериментальные исследования) / М. А. Фесенко // Гигиена труда. - 1989. - № 3. - С. 48-49. 